\title{
Molecular aspects of gefitinib antiproliferative and pro-apoptotic effects in PTEN-positive and PTEN-negative prostate cancer cell lines
}

\author{
C Festuccia ${ }^{1}$, P Muzi ${ }^{1}$, D Millimaggi ${ }^{1}$, L Biordi ${ }^{1}, G$ L Gravina ${ }^{2}, S$ Speca ${ }^{1}$, \\ A Angelucci ${ }^{2}, V$ Dolo $^{1}$, C Vicentini ${ }^{2}$ and $M$ Bologna ${ }^{1,3}$
}

Departments of ${ }^{1}$ Experimental Medicine, ${ }^{2}$ Surgery and ${ }^{3}$ Basic and Applied Biology, University of L'Aquila, Via Vetoio, Coppito-2, 67100 L'Aquila, Italy

(Requests for offprints should be addressed to C Festuccia; Email: festucci@univaq.it)

\begin{abstract}
To date, no effective therapeutic treatment allows abrogation of the progression of prostate cancer (PCa) to more invasive forms. One of the major targets for the therapy in PCa can be epidermal growth factor receptor (EGFR), which signals via the phosphoinositide $3^{\prime}$-kinase (PI3K)/Akt and mitogen-activated protein kinase (MAPK) pathways, among others. Despite multiple reports of overexpression in $\mathrm{PCa}$, the reliance on activated EGFR and its downstream signalling to the PI3K and/or MAPK/extracellular signal-regulated kinase (ERK) pathways has not been fully elucidated. We reported that the EGFR-selective tyrosine kinase inhibitor gefitinib (ZD1839; Iressa) is able to induce growth inhibition, $G_{1}$ arrest and apoptosis in PCa cells and that its effectiveness is associated primarily with phosphatase and tensin homologue deleted from chromosome 10 (PTEN) expression (and thus Akt activity). In fact PTEN-negative PCa cells are slowly sensitive to gefitinib treatment, because this molecule is unable to downregulate PI3K/Akt activity. PI3K inhibition, by LY294002 or after PTEN transfection, restores EGFR-stimulated Akt signalling and sensitizes the cells to pro-apoptotic action of gefitinib. The MAPK pathway seems to be involved primarily on cellgrowth modulation because dual blockade of EGFR and ERK1/2 phosphorylation potentiates growth inhibition (both not cell apoptosis) in PTEN-positive PCa cells and reduced EGFmediated growth in PTEN-negative cells. Thus the effectiveness of gefitinib requires growth factor receptor-stimulated PI3K/Akt and MAPK signalling to be intact and functional. The loss of the PTEN activity leads to uncoupling of this signalling pathway, determining a partial gefitinib resistance. Moreover, gefitinib sensitivity may be maintained in these cells through its inhibitory potential in MAPK/ERK pathway activity, modulating proliferative EGFR-triggered events. Therefore, our data suggest that the inhibition of EGFR signalling can result in a significant growth reduction and in increased apoptosis in EGFR-overexpressing PCa cells with different modalities, which are regulated by PTEN status, and this may have relevance in the clinical setting of $\mathrm{PCa}$.
\end{abstract}

Endocrine-Related Cancer (2005) 12 983-998

\section{Introduction}

Prostate cancer $(\mathrm{PCa})$ is presently the second leading cause of cancer-related death and the most commonly diagnosed non-skin cancer in men. To date, no effective therapeutic treatment allows the abrogation of its progression to more invasive disease forms. In fact, while $\mathrm{PCa}$ is frequently curable in its early stage, approximately one-third of PCa patients present with advanced disease that requires development of novel therapeutic approaches for its control and to improve patient survival. The primary focus of prostate research programs is to understand the molecular mechanism(s) that govern the progression of $\mathrm{PCa}$ from a state of androgen sensitivity to hormone independence with the hope of developing novel 
therapeutic strategies to prevent or delay the progression of PCa to androgen independence, and with the aim of designing targeted therapies.

A central regulator of human PCa progression seems to be the phosphatase and tensin homologue deleted from chromosome 10 (PTEN) tumour-suppressor gene, which maps to 10q23 (reviewed by Osaki et al. 2004). PTEN gene is inactivated in $\sim 50 \%$ of prostate tumours and is correlated with advanced disease and a poor prognosis (Dreher et al. 2004, Pfeil et al. 2004) and Akt activation is probably important for the progression of $\mathrm{PCa}$ to an androgen-independent state. As PTEN encodes a lipid phosphatase that is a negative regulator of the phosphoinositide $3^{\prime}$-kinase (PI3K)/Akt pathway, loss of function for PTEN results in inappropriate activation of Akt and continuous signalling through the PI3K pathway as a result of PTEN deficiency confers protection of PCa cells from cell death and resistance to chemotherapy (reviewed in Wang et al. 2004). However the key role of the PI3K/Akt in promoting cell survival has been well characterized (Brader \& Eccles 2004, Stahl et al. 2004). In addition, PTEN loss-of-function mutations result in homozygous embryonic lethality, whereas heterozygotes have dysplasia and/or carcinoma of many tissues, including prostate (Kim et al. 2002, Abate-Shen et al. 2003, Mazzucchelli et al. 2004). Nkx3.1 $1^{+/-} ;$Pten $^{+/-}$mice develop several key features of the advanced stages of $\mathrm{PCa}$, including invasiveness, the potential for androgen independence and metastases, and a critical dependence on aging for disease progression. In addition, high levels of activated mitogen-activated protein kinase (MAPK) were found in recurrent tumour samples after hormonal therapy (Gioeli et al. 1999).

Two epidermal growth factor (EGF) receptor (EGFR) family members, EGFR (Erb-B1) and Her2 (Erb-B2), are frequently overexpressed in $\mathrm{PCa}$ and this is associated with a more aggressive clinical outcome (Di Loreto et al. 2002). In addition, EGFR/Her2 and its ligands, EGF and transforming growth factor $\alpha$ (TGF $\alpha$ ), play a critical role during tumourigenesis of the prostate gland (Culig et al. 1996, Itoh et al. 1998) and EGFR signalling has been linked to the progression of androgen-responsive PCa to androgenindependent/hormone refractory tumours (Djakiew 2000, El Sheikh et al. 2004, Gravina et al. 2004, Festuccia et al. 2005). Elevated expression of both EGFR and its ligands have been described in prostate tumours (Djakiew 2000) and in vitro studies have indicated that the growth of the androgen-independent prostate tumour cell line DU145 is regulated by the autocrine activation of the EGFR by EGF and TGF $\alpha$
(Connolly \& Rose 1991). Furthermore, preclinical data have suggested that the EGFR signalling pathway can activate the androgen receptor under conditions of clinical androgen deprivation (Barton et al. 2001, Festuccia et al. 2005). The EGFR or Erb-B1 is a proto-oncogene, which encodes a $170 \mathrm{kDa}$ protein that consists of an extracellular ligand-binding domain, a transmembrane domain, an intracellular tyrosine kinase domain and a $\mathrm{C}$-terminal regulatory domain containing sites of autophosphorylation. Upon binding of its ligands, EGFR will undergo homo- and/or heterodimerization with other members of this receptor family including Erb-B2, Erb-B3 and Erb-B4, resulting in addition of phosphate moieties to specific tyrosines, which can serve as docking sites for downstream effectors. This triggers a cascade of biochemical and physiological responses that constitute the mitogenic signal transduction of the cells. Several kinase cascades have been implicated in signal transduction through the Erb-B receptors including the Ras/Raf and PI3K/Akt pathways.

Given the frequency at which abnormalities in EGFR signalling are present in malignant $\mathrm{PCa}$ and the demonstrated roles of these changes in the transformation and production of phenotypes associated with increased malignancy of PCas, this receptor is an attractive target for therapeutic manipulation. Gefitinib (Iressa) is an oral anilinoquinazolone compound that inhibits the tyrosine kinase activity of the EGFR (Ciardiello et al. 2000, Arteaga \& Johnson 2001), resulting in the inhibition of the activation of downstream signalling molecules.

Gefitinib presents much therapeutic promise for the treatment of numerous human cancer types; however, the clinical data demonstrate that not all patients respond to the inhibitor, indicating the existence of intrinsic or de novo resistance to the drug (Barton et al. 2001, Cohen et al. 2002, Fukuoka et al. 2002, Goss et al. 2002, Herbst \& Kies 2002, Ranson 2002). PTEN absence has been associated with gefitinib resistance in several cancers (She et al. 2003) and basal activation of extracellular signal-regulated kinase (ERK) $1 / 2$ seems to prevent the effectiveness of EGFR inhibitors in breast cancer cells (Ono et al. 2004).

Gefitinib inhibits the growth of cell lines that express high levels of both EGFR and Her2 (Vicentini et al. 2003), induces complete regression of well-established xenografts (Ciardiello et al. 2000, Sirotnak et al. 2002, Asakuma et al. 2004) and has recently entered clinical trials in cancer patients (Lorusso 2003, Natale 2004, Wolf et al. 2004). Intrinsic and acquired resistance to chemotherapy is a major obstacle to successful cancer treatment. Understanding the mechanisms by which 
tumours become resistant to a particular agent is key to identifying new drugs or combination regimens. The acquisition of resistance to gefitinib has also been demonstrated in vitro, with the establishment of a gefitinib-resistant PC-9 NSCLC cell line, being observed following a stepwise dose escalation of the compound over 1 year (Yamakoa et al. 2002). Furthermore, other studies have demonstrated that resistance to the inhibitor developed after several generations of treatment in $\mathrm{PCa}$ xenografts (Geller et al. 2002). Development of resistance has also been described with other signal transduction inhibitors such as trastuzumab (Herceptin). Resistance to this human antibody directed against the extracellular domain of Erb-B2, used in the treatment of Erb-B2positive metastatic breast cancer, has been reported to occur within 12 months (Baselga 2001, Slamon et al. 2001). It is possible that resistance to gefitinib may be acquired by the ability of the tumour cells to utilize alternative growth factor pathways in the presence of the drug. EGFR-overexpressing MDA-MB468 breast cancer cells lacking PTEN function are resistant to gefitinib (She et al. 2003), and this drug is unable to downregulate Akt activity in these cells while pharmacologic downregulation of constitutive PI3K/Akt pathway signalling using the PI3K inhibitor LY294002 restores EGFR-stimulated Akt signalling and sensitizes cells to gefitinib. These results suggested that sensitivity to gefitinib requires intact growth factor receptor-stimulated Akt signalling activity

Our study determined whether there is a correlation between the effectiveness of gefitinib and EGFR/Her2 status, and PI3K or MAPK activity in PCa cells, and how this affects the response to an inhibitor of the receptor. We reported that PTEN-negative PCa cells are only partially resistant to gefitinib treatment because this molecule is unable to downregulate PI3K/Akt activity in these cells. Comparing PTENnegative with PTEN-positive cells we observed that exposure to gefitinib induced differential patterns of cell-cycle arrest and apoptosis features as well as distinct patterns of effects on Akt, ERK1/2, c-Jun N-terminal kinase (JNK) $1 / 2$ and p38 MAPK phosphorylation.

\section{Materials and methods}

\section{Reagents}

All the materials for tissue culture were purchased from Hyclone (Cramlington, NE, USA). Plasticware was obtained from Nunc (Roskilde, Denmark). EGF was purchased from Immuno Tools $\mathrm{GmbH}$ (Friesoythe, Germany). Gefitinib was obtained from AstraZeneca. Antibodies were purchased from Santa Cruz Biotechnology (Santa Cruz, CA, USA) unless otherwise indicated. PTEN antibody has been purchased from Sigma Chemical Co. (St Louis, MO, USA). Antibodies against phosphorylated forms of EGFR, HER2 and ERK1/2 were obtained from Biosource International (Camarillo, CA, USA). Akt/ protein kinase B (PKB) kinase activity was performed using a non-radiactive assay kit (StressXpress AKT/ PKB Elisa kit) which was purchased from Stressgene Bioreagents (Victoria, BC, Canada) on cell lysates after partial purification on a MonoQ exchange column ( $2 \mathrm{mg}$ protein in $1 \mathrm{ml}$ column) with $10 \mathrm{mM}$ MOPS, pH 7.2, $25 \mathrm{mM} \beta$-glycerophosphate, $5 \mathrm{mM}$ EGTA, $2 \mathrm{mM}$ EDTA, $2 \mathrm{mM}$ sodium orthovanadate and $2 \mathrm{mM}$ dithiothreitol and eluted using $12 \mathrm{ml}$ linear $\mathrm{NaCl}$ gradient $(0-0.8 \mathrm{M} \mathrm{NaCl})$ with a flow rate of $0.5 \mathrm{ml} / \mathrm{min}$. We collected fractions between 0.25 and $0.5 \mathrm{ml}$ for analysis.

\section{Cell lines}

We used three androgen-sensitive PCa cell lines (ND1, LnCaP and CWR22R-2152 xenograft-derived) and four androgen-insensitive PCa cell lines (PC3, DU145, ALVA31 and TSU-Pr1). CWR22R-2152 cell cultures were obtained in our laboratory from a xenografted CWR22 relapsed tumour (Tepper et al. 2002) kindly provided by Dr T Pretlow (Case Western Reserve University, Cleveland, OH, USA). LnCaP, PC3 and DU145 cell lines were originally obtained from ATCC (Rockville, MD, USA). ND1 cells (Narayan \& Dahiya 1992) were kindly provided by Dr R Dahiya (University of California, San Francisco, CA, USA), TSU-Pr1 cells (Izumi et al. 1987) were kindly provided by Dr K Takeda (Science University of Tokyo, Tokyo, Japan) and ALVA31 cells (Loop et al. 1993) were kindly provided by B A Roos (Univerity of Miami, Coral Gables, FL, USA). PTEN-transfected PC3 cells (Zhao et al. 2004) were kindly provided by Dr D LeRoith (National Institutes of Health, Bethesda, MD, USA).

\section{Reverse transcriptase (RT)-PCR for PTEN expression}

Total RNA was extracted from PCa cells lines with Trizol reagent (Life Technologies, Gaithersburg, MD, USA) according to the manufacturer's instructions. An RT-PCR was carried out on DNase Amp Grade (Gibco-BRL)-treated RNA using Murine Leukaemia Virus (MuLV) RT (50 U) in $100 \mathrm{mM}$ Tris $/ \mathrm{HCl}, \mathrm{pH} 8.3$, 
$500 \mathrm{mM} \mathrm{KCl}, 5 \mathrm{mM} \mathrm{MgCl}_{2}, 0.5 \mu \mathrm{M}$ each dNTP, $1 \mathrm{U}$ RNasin and 500 pmol random examer primers. cDNA $(2 \mu \mathrm{l})$ were amplified in a $50 \mu \mathrm{l}$ reaction volume containing $0.5 \mu \mathrm{M}$ sense and antisense primers, 2.5 $\mathrm{U} \mathrm{Taq}$ DNA polymerase (Applied Biosystems, Milan, Italy), $200 \mu \mathrm{M}$ each dNTP and $1.5 \mathrm{mM} \mathrm{MgCl}_{2}$. A coamplification of GAPDH was performed. Primer sequences used for PCR were: PTEN 3rd exon, forward, 5'-ATATTCTCTGAAAAGCTCTGG-3', and reverse, 5'-TTAATCGGTTTAGGAATCAA- ${ }^{\prime}$; GAPDH, forward, 5'-CACCATGGAGAAAGGCCGGGG-3', and reverse, 5'-GACGGACACATTGGGGGTAG-3'. After amplification, $20 \mu 1$ of the PCR reaction mixture was analysed by $1.2 \%$ agarose gel electrophoresis and stained with ethidium bromide.

\section{Growth assays}

Cells were seeded at a density of $2 \times 10^{4}$ cells per dish on $50 \mathrm{~mm}$ petri dishes. Cells were left to attach and grow in 5\% fetal calf serum/Dulbecco's modified Eagle's medium (DMEM) for $24 \mathrm{~h}$. After this time, cells were maintained in culture medium containing androgens or subjected to androgen depletion. All other cells were treated with either $50 \mathrm{ng} / \mathrm{ml} \mathrm{EGF}$ or different doses of gefitinib and/or inhibitors of single molecules involved in EGFR-mediated signalling (LY294002, a PI3K inhibitor; PD98059 and U0126, which are MAPK/ERK kinase (MEK) inhibitors; SB203580, a p38 MAPK inhibitor; and SP600125, a JNK inhibitor) at the recommended inhibition doses. Cells trypsinized and resuspended in $20 \mathrm{ml}$ saline were counted using a haemocytometer every $24 \mathrm{~h}$ (LabRecyclers, Gaithersburg, MD, USA); five independent counts were performed for each dish. All experiments were conducted in triplicate. To evaluate the effective cell proliferation we measured the uptake of $\left[{ }^{3} \mathrm{H}\right]$ thymidine as described in the next section. To calculate the inhibitory concentrations at $50 \% \quad\left(\mathrm{IC}_{50}\right)$ of gefitinib, 2500 cells were cultured in 96-well plates for 24-96 h. After adhesion (16h) cells were grown under different culture conditions (see above). After 48-96 h the cells were exposed for $4 \mathrm{~h}$ to thiazol blue (MTS; Promega, Madison, WI, USA). The 96-well culture plates were then placed on a microplate shaker for $5 \mathrm{~min}$ and the absorbance of the converted dye was measured at the wavelength of $490 \mathrm{~nm}$ using a Biorad multiscan plate reader (Bio-Rad, Richmond, CA, USA). Usually, five replicate wells were used for each group. Inhibition curves were plotted using means of values obtained from $\mathrm{OD}$ percentages relative to control values for each concentration. $\mathrm{IC}_{50}$ values were calculated by the GraFit method (Erithacus
Software, Staines, Middx, UK) considering the slopes of inhibition curves obtained for each group of tests.

\section{Assessment of thymidine incorporation in gefitinib-treated PCa cells}

Cell-proliferation studies were performed by measuring the uptake of $\left[{ }^{3} \mathrm{H}\right]$ thymidine. Briefly, $\mathrm{PCa}$ cells $\left((1-2) \times 10^{4}\right.$ cells/well $)$ were grown overnight in 24-well plates and exposed to either gefitinib (0.1$10 \mu \mathrm{M})$ or DMEM (control). After treatment, cells were pulsed with $\left[{ }^{3} \mathrm{H}\right]$ thymidine $(1 \mu \mathrm{Ci} /$ well $)$ for $4-6 \mathrm{~h}$, fixed with $5 \%$ trichloroacetic acid and solubilized in $0.5 \mathrm{M} \mathrm{NaOH}$ before scintillation counting. Experiments were performed in triplicate.

\section{Preparation of cell lysates and western blot analysis}

Following treatment, cells were washed with cold PBS and immediately lysed with $1 \mathrm{ml}$ lysis buffer $(50 \mathrm{mM}$ HEPES, pH 7.5, $150 \mathrm{mM} \mathrm{NaCl}, 10 \%$ glycerol, $1 \%$ Triton X-100, $1 \mathrm{mM}$ EDTA, $1 \mathrm{mM}$ EGTA, $50 \mathrm{mM}$ $\mathrm{NaF}, 1 \mathrm{mM}$ sodium orthovanadate, $30 \mathrm{mM}$ p-nitrophenyl phosphate, $10 \mathrm{mM}$ sodium pyrophosphate, $1 \mathrm{mM}$ PMSF, $10 \mu \mathrm{g} / \mathrm{ml}$ aprotinin and $10 \mu \mathrm{g} / \mathrm{ml}$ leupeptin). Lysates were electrophoresed by $7 \% \mathrm{SDS} / \mathrm{PAGE}$, and separated proteins transferred to nitrocellulose and probed with the appropriate antibodies using the conditions recommended by the suppliers. EGFR and ERK activation status was analysed using phosphospecific antibodies, and blots were stripped and reprobed with the appropriate antibody for assessment of total ERK or EGFR expression.

\section{Immunofluorescence analysis}

Quantification of EGFR/HER2-positive cells was performed by flow-cytometric analysis (FACScan; Becton Dickinson, Mountain View, CA, USA). Cells were trypsinized, centrifuged and left at $37^{\circ} \mathrm{C}$ for $1 \mathrm{~h}$ in DMEM $/ 10 \%$ fetal calf serum in polypropylene tubes to reconstitute cellular external membrane. Cells were washed in saline buffer and $1 \times 10^{6}$ cells were fixed in a $3.7 \%$ paraformaldehyde-buffered solution, washed twice and treated with about $10 \mu \mathrm{g} / \mathrm{ml}$ primary antibodies. After $1 \mathrm{~h}$ at $4{ }^{\circ} \mathrm{C}$ cells were washed twice in PBS and FITC-conjugated anti-rabbit and anti-mouse secondary antibodies (about $1 \mu \mathrm{g} / \mathrm{ml}$ ) were added to the fixed cells. After $30 \mathrm{~min}$ of incubation at $4^{\circ} \mathrm{C}$, cells were washed twice and resunspended in PBS at $1 \times 10^{6}$ cells $/ \mathrm{ml}$ before analysis using Cell Quest software (Becton Dickinson). 


\section{Cell-cycle and apoptosis analysis}

The adherent cells were trypsinized, pooled with the culture supernatant containing the apoptotic cells already detached from the dish and centrifuged. Cells $\left(1 \times 10^{6}\right)$ were washed in PBS and fixed for $30 \mathrm{~min}$ by the addition of $1 \mathrm{ml} 70 \%$ ethanol. After $30 \mathrm{~min}$, the cells were pelleted by centrifugation $(720 \mathrm{~g} ; 5 \mathrm{~min})$, and resunspended in $1 \mathrm{ml}$ of DNA staining solution (PBS containing $200 \mathrm{mg} / \mathrm{ml}$ RNase A, $20 \mathrm{mg} / \mathrm{ml}$ propidium iodide and $0.1 \%$ Triton $\mathrm{X}-100$ ) and stained by incubation at room temperature for $60 \mathrm{~min}$. All cells were then measured on a FACScan flow cytometer with an argon laser at $488 \mathrm{~nm}$ for excitation and analysed using Cell Quest software. All flowcytometric measurements were made using the same instrument settings, and at least 10000 cells were measured in each sample. Apoptotic cells were detected by a quantifiable peak in sub- $\mathrm{G}_{1}$ phase corresponding to the red fluorescent light emitted by sub-diploid nuclei of cells, and the results were expressed as the percentage of death by apoptosis induced by a particular treatment.

\section{Statistics}

Statistical analysis was performed using SPSS 11.0 software (SPSS, Chicago, IL, USA). All $P$ values less than 0.05 were considered to indicate significance. All statistical tests were two-tailed. Differences in ordinary variables were compared with $\chi^{2}$ test for $2 \times 2$ tables or Fisher's exact test when the tables were too sparse. Continuous variables were analysed using the Wilcoxon rank sum test. Whenever we correlated a continuous variable with a dichotomy or an ordinal variable, as a measure of the strength of a relationship, we used the Point-biserial correlation.

\section{Results}

\section{Antiproliferative effects of gefitinib}

We analysed in PCa cells the expression of (1) PTEN, by western blotting and RT-PCR, (2) phospho- (p-) Akt and Akt activity, by western blotting and Akt/ PKB kinase activity assay kit, (3) p-ERK1/2 by western blotting, and (4) EGFR and Her2, by FACS analysis. In addition we compared the levels of the above-mentioned parameters with gefitinib effectiveness as shown in Fig. 1 and Table 1.

RT-PCR analysis revealed that PC3, ALVA31 and TSU-Pr1 cells do not express PTEN mRNA whereas ND1， LnCaP， CWR22R-2152 and DU145 cells were PTEN-positive (Fig. 1A). Western blot analysis
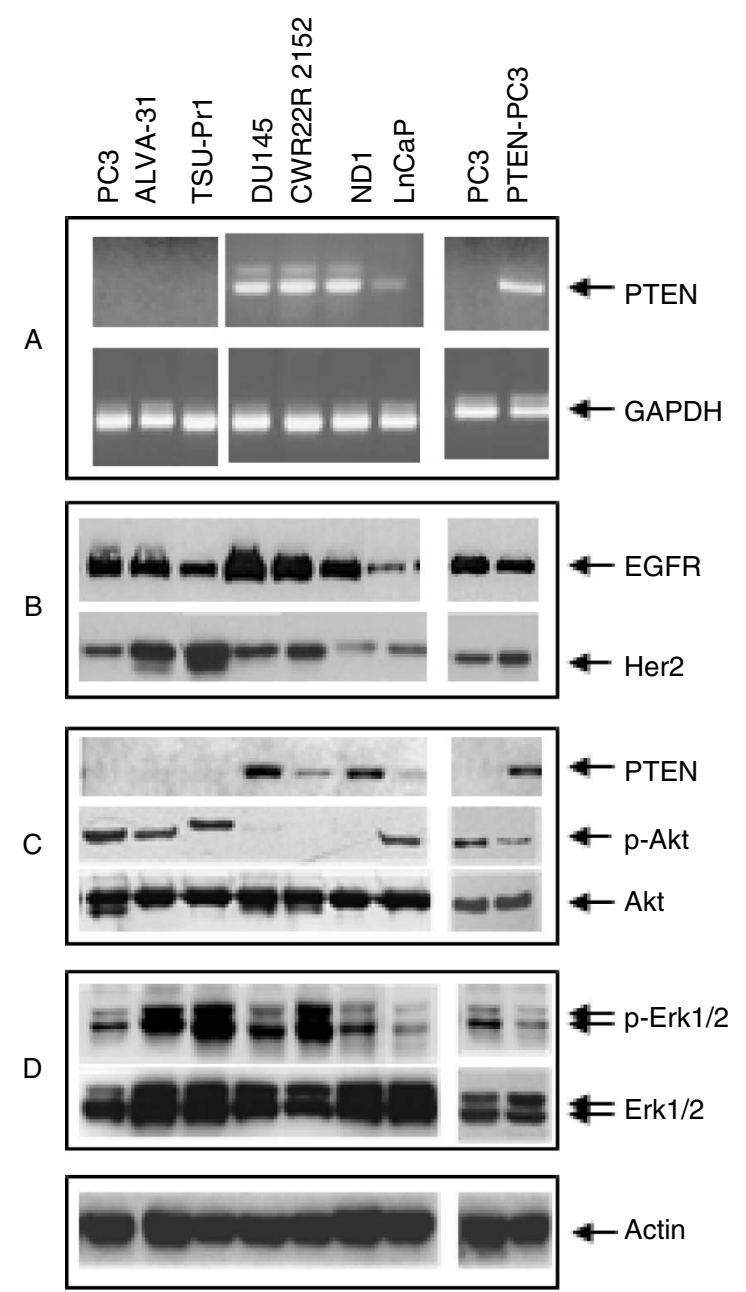

Figure 1 Expression of (A, C) PTEN by (A) RT-PCR and (C) Western blotting, (B) EGFR and Her2, (C) Akt and p-Akt and (D) p-ERK1/2 and total ERK compared with actin levels in eight $\mathrm{PCa}$ cell lines. Total RNA was extracted from PCa cells with Trizol reagent as described in the Materials and methods section. After amplification, $20 \mu \mathrm{l}$ of PCR mixture was analysed by $1.2 \%$ agarose gel electrophoresis and stained with ethidium bromide. Total protein extracts were harvested as described and $40 \mu \mathrm{g} / \mathrm{lane}$ loaded for western blot analysis. Filters were blotted for different antibodies as described. For analysis of activated (phosphorylated) forms of Akt and ERK filters were blotted with anti-phosphorylated forms and reprobed after stripping with antibodies against total protein forms.

revealed that ND1, DU145 and CWR22R-2152 cells express PTEN protein whereas $\mathrm{LnCaP}$ cells, in agreement with some reports, do not express this protein (Fig. 1B). PTEN protein-negative cells possess higher levels of activated (phosphorylated) Akt (p-Akt) compared with PTEN protein-positive cells (Fig. 1B and $\mathrm{C}$ ). 
Table 1 Characterization of the eight tested PCa cell lines

\begin{tabular}{lccccccr}
\hline Cell line & PTEN & Akt/PKB & p-Erk & EGFR & Her2 & IC $_{\text {50 }}$ Gefitinib & Apoptosis (\%) \\
\hline PC3 & - & 5.5 & 1.5 & 4.8 & 3.0 & 0.70 & 10 \\
PC3-PTEN & + & 0.1 & 0.6 & 4.0 & 3.0 & 0.25 & 38 \\
ALVA31 & - & 7.8 & 4.0 & 3.0 & 5.7 & 0.89 & 5 \\
TSU-Pr1 & - & 10.4 & 5.2 & 1.5 & 7.0 & 1.0 & 5 \\
DU145 & + & 0.3 & 2.0 & 9.0 & 4.0 & 0.55 & 35 \\
ND1 & + & 0.1 & 3.0 & 2.5 & 1.5 & 0.90 & \\
CWR22R-2152 & + & 0.1 & 1.7 & 5.9 & 2.0 & 0.20 & \\
LnCaP & \pm & 1.5 & 0.8 & 2.0 & 1.5 & 0.37 &
\end{tabular}

PTEN expression was evaluated by both RT-PCR and western blotting analysis, thus - represents the absence and +the presence of PTEN, LnCaP cells contain detectable levels of mRNA for PTEN but not of PTEN protein (therefore we used the \pm symbol). Akt/PKB activity was evaluated by ELISA test and the values represent the ng of active protein present in the test (produced by $1 \times 10^{6}$ cells). Erk activity was evaluated densitometrically by dosing the OD of $p$-Erk $1 / 2$ bands generated by western blotting with respect to total Erk. EGFR and Her2 levels were evaluated by FACS using a fluorescence index generated in our experiments. $I_{50}$ values for gefitinib were evaluated using MTS assay as described in Materials and methods section, whereas apoptosis was measured after $48 \mathrm{~h}$ of incubation with $0.5 \mu \mathrm{M}$ gefitinib.

The $\mathrm{IC}_{50}$ values for gefitinib observed in PTENnegative and PTEN-positive cells were not statistically different $(0.74 \pm 0.28$ versus $0.55 \pm 0.35 \mu \mathrm{M}$, respectively) and PTEN-transfected PC3 cells (Zhao et al. 2004) were more sensitive than wild-type PC3 cells $(0.25$ versus $0.70 \mu \mathrm{M})$. These results indicate that the drug's antiproliferative effectiveness, evaluated by $\mathrm{IC}_{50}$ value, could be not completely dependent on PTEN function. In contrast, the correlation between the effectiveness of gefitinib and basal Akt activity revealed $r=0.709(P=0.049$; Fig. $1 \mathrm{C}$ and Table 1$)$, suggesting that the elevated basal Akt activity was a negative parameter for gefitinib efficacy.

Next we verified whether gefitinib effectiveness was associated with $\mathrm{p}$-ERK1/2 basal levels. To compare the levels of basal ERK1/2 activation in each tested cell line, we quantified the activation of ERK1/2 (p-ERK) densitometrically. Densitometry of immunoreactive bands showed the phosphorylation of ERK1/2 with respect to total ERK. Immunoblotting revealed differences in the basal levels of ERK1/2 phosphorylation in different $\mathrm{PCa}$ cell lines, whereas the expression of ERK1/2 protein, normalized to actin expression, was relatively consistent, as shown in Fig. 1D. The $\mathrm{IC}_{50}$ values for gefitinib treatment were statistically and positively related to ERK $1 / 2$ status $(r=0.849$; $P<0.01)$ and the inhibition of growth by gefitinib was most effective in cells with low p-ERK1/2 levels (Table 1).

In addition, we examined gefitinib effectiveness with respect to EGFR levels. The correlation analysis revealed that gefitinib effectiveness was independent of EGFR levels $(r=-0.411 ; P=0.312$, not significant). However, the effects of gefitinib were most evident in cells with high levels of EGFR and nonactivated ERK1/2 (CWR22R-2152 and PTENtransfected PC3 cells) when compared with cells with high EGFR and high basal levels of phosphorylated ERK1/2 (DU145 cells).

Next, we compared gefitinib effectiveness with Her2 levels (Table 1). The analysis of the correlation revealed that gefitinib effectiveness was independent for Her2 levels $(r=0.594 ; P=0.12)$. However, the effects of gefitinib were most evident in cells with low levels of Her2 and nonactivated ERK1/2 (CWR22R2152, LnCaP, DU145 and PTEN-transfected PC3 cells) when compared with cells with high Her2 and basal levels of phosphorylated ERK1/2 (TSU-Pr1 and ALVA31 cells).

As previously observed (Vicentini et al. 2003) gefitinib induced a dose-dependent $\mathrm{G}_{0} / \mathrm{G}_{1}$ proliferative arrest with apoptosis induction in $\mathrm{PCa}$ cells. We observed that the percentage of apoptotic cells, measured at $48 \mathrm{~h}$ in the presence of $0.5 \mu \mathrm{M}$ gefitinib, is considerably lower in PTEN-negative than PTENpositive cells $(11.0 \pm 6.0$ versus $33.0 \pm 6.0 \%$, respectively; $P<0.05$ ), whereas no statistical significance was demonstrated when we compared apoptosis with ERK activation. A negative correlation was observed comparing Akt activity and gefitinib-induced apoptosis $(r=-0.828 ; P<0.001)$, suggesting that the elevated Akt activity is protective for gefitinib-induced cell apoptosis.

Taken together, the data illustrated in this section indicate that MAPK activity modulates primarily the antiproliferative effects of gefitinib whereas PTEN modulates the pro-apoptotic activities of this drug. 
A
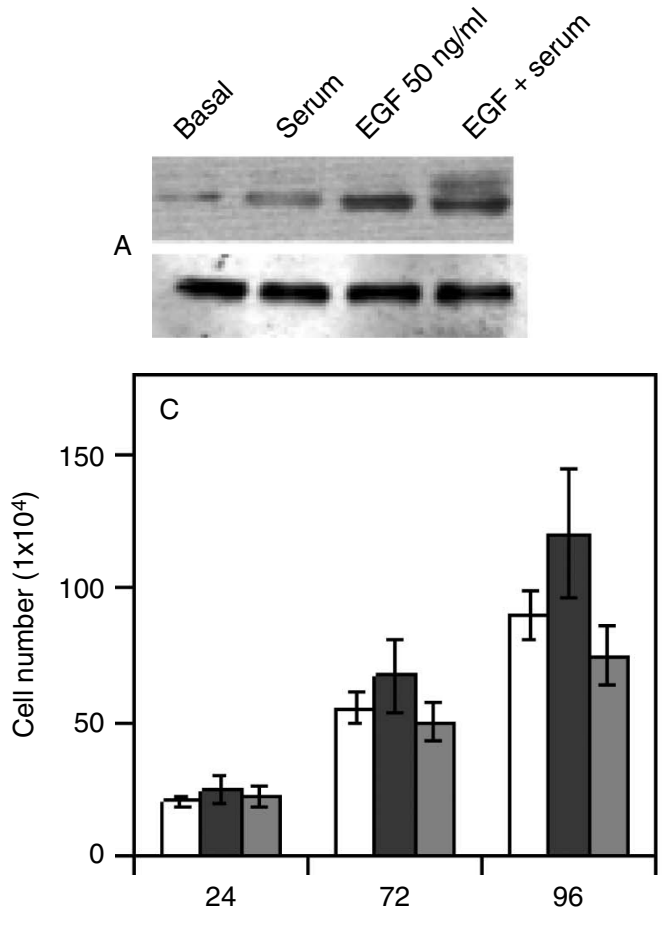

Time of culture $(\mathrm{hr})$
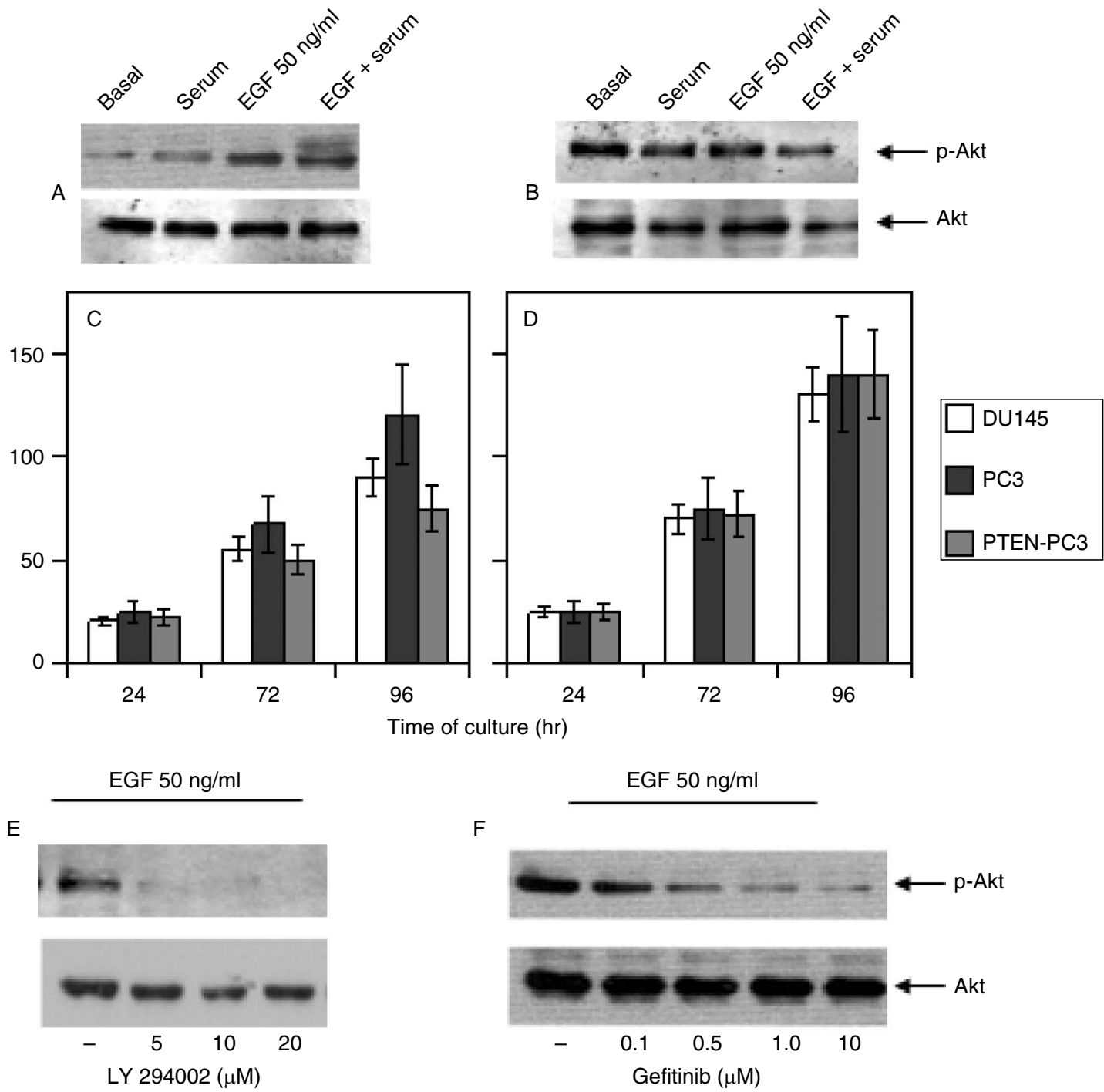

Figure 2 Akt activition in DU145 (A) and PC3 (B) cells by $10 \%$ serum and/or by $50 \mathrm{ng} / \mathrm{ml}$ EGF. PTEN transfection reduces growth of PC3 cells in the basal condition (C) but not in the presence of $50 \mathrm{ng} / \mathrm{ml}$ EGF (D) as shown also in DU145 cell line; LY295002 (E) and gefitinib $(F)$ reduce dose-dependently the EGF-mediated p-Akt activity in DU145 cells. We treated PCa cells with $50 \mathrm{ng} / \mathrm{ml}$ EGF for $30 \mathrm{~min}$ in the presence or absence of $10 \%$ serum and verified PI3K activity by evaluating phosphorylation of Akt in Western blotting, loading $40 \mu \mathrm{g}$ protein cell extract/lane. Filters were stripped and blotted with an antibody against total Akt. Akt activation is modulated after EGF treatment only in DU145 cells whereas Akt activation is not affected by EGF in PC3 cells possessing elevated basal PI3K activity. Then the effects of LY294002 and getifinib were evaluated in DU145 cells. Tyrosine kinase inhibitors were added $15 \mathrm{~min}$ prior to $50 \mathrm{ng} / \mathrm{ml}$ EGF treatment. EGF was left $30 \mathrm{~min}$ prior to cell-extract preparation. Gefitinib and LY294002 were dissolved in DMSO and used at a final concentration of $0.1 \%$. The results are representative of at least three independent experiments.

\section{PC3 and DU-145 cells have distinct PTEN expression and Akt activation}

In Fig. 2 we show that PTEN-positive (DU145 cells; Fig. 2A) and PTEN-negative (PC3 cells; Fig. 2B) cells have basally different levels of the activated form of Akt (p-Akt). EGF and serum increased Akt activation only in DU145 cells. In serum-free conditions PC3 cells were more proliferating than DU145 cells, and the reintroduction of PTEN in PC3 cells by transfection (PTEN-PC3) reduced cell proliferation, as shown in Fig. 2C and in agreement with several data-sets obtained with other PTEN-transfected cells. Moreover, EGF increased DU145 cell proliferation strongly 
(as well as PTEN-PC3 cell proliferation), whereas it only increased cell proliferation weakly in PC3 cells (Fig. 2D).

An inhibitor of PI3K (LY294002) was able to inhibit EGF-mediated p-Akt expression in DU145 cells (Fig. 2E). In contrast, LY294002 inhibited the basal p-Akt expression in PC3 cells (data not shown). Gefitinib was able to reduce EGF-mediated p-Akt expression in DU145 cells (Fig. 2F), suggesting that in these cells the effects of gefitinib were associated with Akt downmodulation.

\section{Gefitinib was able to reduce PC3 and DU145 cell proliferation}

As shown in Fig. 3, growth of DU145 cells (B) was strongly inhibited by gefitinib in a dose-dependent manner with an $\mathrm{IC}_{50}$ of $0.35 \mu \mathrm{M}$ when cells were cultured in serum-free medium plus EGF. The gefitinib effect was less in PC3 cells (A), with an $\mathrm{IC}_{50}$ value of $0.70 \mu \mathrm{M}$. Serum was able to reduce the effects of gefitinib significantly. Under these conditions the $\mathrm{IC}_{50}$ values for gefitinib in both cell lines were similar $(0.55 \mu \mathrm{M}$ for DU145 and $0.75 \mu \mathrm{M}$ for PC 3 cells). The growth-curve analyses were in agreement with results from $\left[{ }^{3} \mathrm{H}\right]$ thymidine uptake (Fig. $3 \mathrm{C}$ ) in these cells.

\section{LY294002 treatment sensitizes PTEN-negative cells to gefitinib antiproliferative and pro-apoptotic actions}

PC3, DU145 and PTEN-transfected PC3 cells were tested for proliferation and apoptosis after treatment with two structurally distinct and specific PI3K inhibitors, wortmannin and LY294002. To elucidate the role of PI3K in regulating proliferation, cells were seeded and cultured for $24 \mathrm{~h}$, followed by incubation in the presence or absence of PI3K inhibitors and cell number, $\left[{ }^{3} \mathrm{H}\right]$ thymidine uptake and the cell cycle at 24 , 48 and $72 \mathrm{~h}$ of incubation were analysed. PI3K inhibition with $30 \mu \mathrm{M}$ LY294002 induced relatively lower basal inhibitory effects in DU145 and PTENtransfected PC3 cells when compared with wild-type PC3 cells (Fig. 4A). Antiproliferative effects induced by LY294002 were attenuated by EGF, especially in PC3 cells. In fact, in the presence of EGF the growth of DU145 cells was significantly inhibited by LY294002 treatment whereas weaker effects were observed in PC3 cells (Fig. 4B).

Thus Erb-B1 activation is able to reduce the antiproliferative effect of PI3K inhibitors only in PC3 cells. Therefore dual inhibition of EGFR and PI3K activities may theoretically be additive. Next we performed combined experiments in PTEN-positive

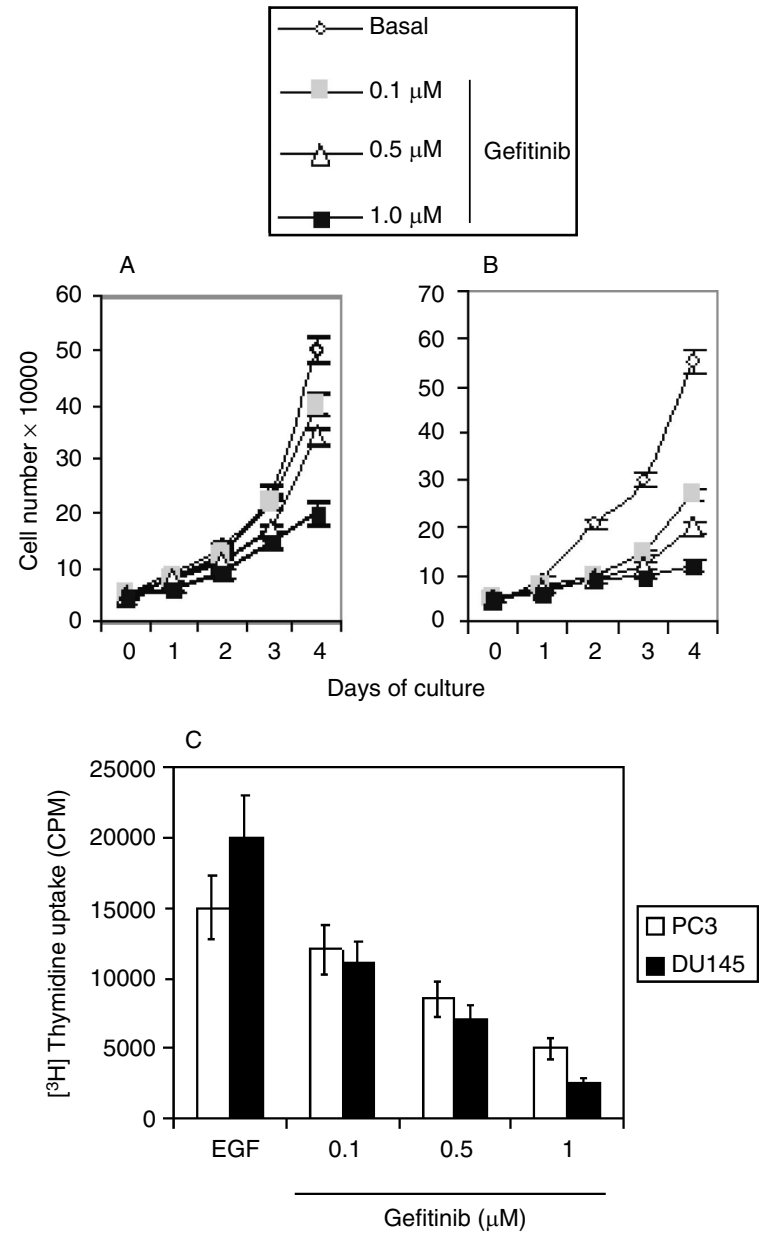

Figure 3 Proliferative effects of gefitinib in PC3 $(A, C)$ and DU145 (B, C) cells in serum-free medium and $50 \mathrm{ng} / \mathrm{ml}$ EGF. Proliferation was evaluated as described on different days of culture in the presence of $0.1,0.5$ and $1.0 \mu \mathrm{M}$ gefitinib by cell counts and $\left[{ }^{3} \mathrm{H}\right]$ thymidine incorporation. The data are expressed as means \pm S.D. The results are representative of at least three independent experiments.

and PTEN-negative cells, as shown in Fig. 5. Growth curves (Fig. 5A and B) and $\left[{ }^{3} \mathrm{H}\right]$ thymidine uptake (Fig. 5C) indicated that LY294002 possesses additive effects in PTEN-positive cells and synergistic effects in PTEN-null cells.

\section{PI3K regulates $G_{1}$ cell-cycle progression in PCa cells}

To determine whether the inhibition of PI3K activity by LY294002 affects cell-cycle progression, DU145, PC3 and PTEN-PC3 cells were treated as described above and cell-cycle distribution was analysed by flow cytometry. We observed that LY294002 determines a 


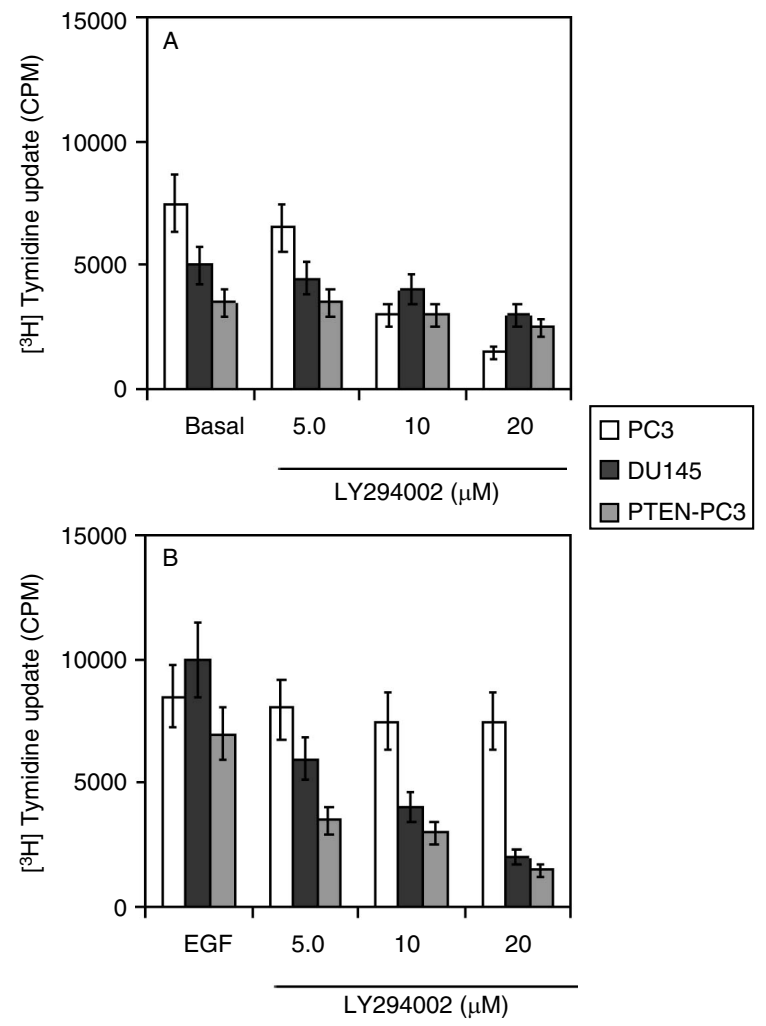

Figure 4 Evaluation of antiproliferative effects of LY294002 in PC3, DU145 and PTEN-PC3 cells under basal (A) and EGF-stimulated (B) conditions. LY294002, a PI3K inhibitor, reduces basal cell proliferation of PTEN-negative PC3 cells in a dose-dependent manner. Also, DU145 and PTEN-PC3 cells were inhibited by LY294002 after treatment with $50 \mathrm{ng} / \mathrm{ml}$ EGF.

$\mathrm{G}_{0} / \mathrm{G}_{1}$ arrest, especially in PTEN-null PC3 cells followed by a strong cell apoptosis, evident after $48 \mathrm{~h}$, in a dose-dependent manner. Serum presence and EGF partially counteracted apoptotic events in PC3 cells. LY294002 induced apoptosis strongly after EGF treatment in DU145 and PTEN-PC3 cells, as shown in Table 2. In Fig. 6 we show the FACS profiles in PC3 cells treated with $10 \mu \mathrm{M}$ LY 294002 and $1 \mu \mathrm{M}$ gefitinib alone or in combination. The numerical data are summarized in Table 3 whereas Table 4 shows the dual blockade of EGFR and PI3K phosphorylation effects in the eight PCa cell lines tested.

\section{Dual blockade of EGFR and MAPK activity potentiates growth inhibition of PCa cells in PTEN-positive cells}

Since inhibition of the PI3K/Akt pathway appears to be important but not sufficient for gefitinib-mediated growth inhibition, we decided to study the effects of

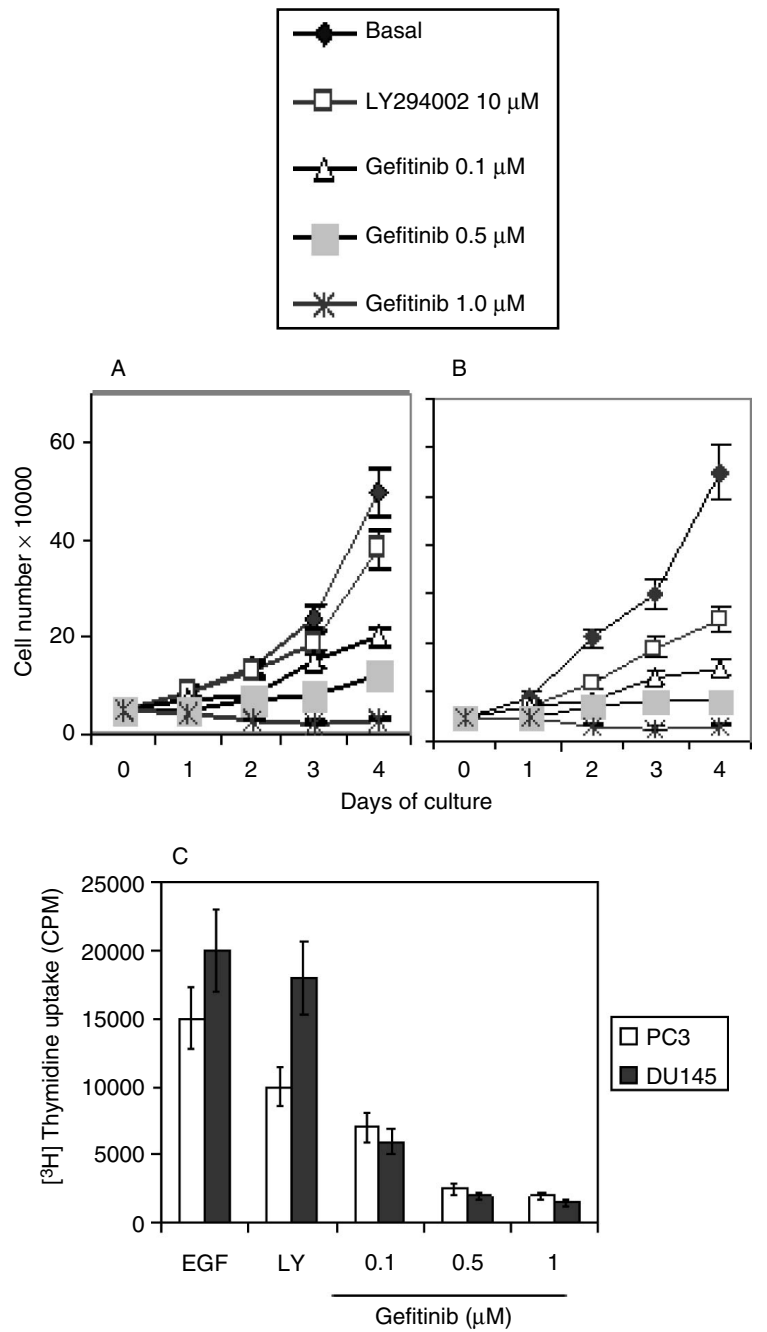

Figure 5 Evaluation of antiproliferative effects of LY294002 in PC3 (A, C) and DU145 (B, C) in combination with gefitinib. LY294002 sensitizes PC3 cells to EGFR inhibition, resulting synergistic with gefitinib. PI3K inhibition was very weakly additive in DU145 cells as summarized in Table 4.

gefitinib on MAPK pathways. The ERK/MAPK pathway is a prominent signalling pathway activated by receptor tyrosine kinases, including Erb-B1. PC3, DU145 and PTEN-transfected PC3 cells were tested for proliferation and apoptosis after treatment with two MAPK inhibitors, PD98059 and U0126. First we observed that EGF induced a dose-dependent ERK activation; this effect was abolished by MAPK pathway inhibitors (50 $\mu \mathrm{M}$ PD98059 and U0126) and by gefitinib in all cell lines. PD98059 is a potent, selective and cell-permeable inhibitor of MAPK kinase and inhibits phosphorylation of MAPK. U0126 is a potent and selective MEK1/2 inhibitor. In Fig. 7A we show 
Table 2 Effect of PI3K inhibitor (LY294002; L4) on apoptosis of PC3 (PTEN-negative) and DU145 (PTEN-positive) cells in the presence of serum or EGF. Similar differences were observed for other PTEN-negative or -positive cells. Apoptotic cells were detected by a quantifiable peak in sub-G1 phase corresponding to the red fluorescence emitted by a sub-diploid nuclei of cells, and the result were expressed as the cell death percentage present in the sample.

\begin{tabular}{|c|c|c|c|c|c|c|}
\hline \multirow[b]{2}{*}{ Cell line } & \multicolumn{2}{|c|}{ Basal } & \multicolumn{2}{|c|}{ Serum $(10 \%)$} & \multicolumn{2}{|c|}{ EGF $(50 \mathrm{ng} / \mathrm{ml})$} \\
\hline & - & + L4 $(10 \mu \mathrm{M})$ & - & + L4 (10 $\mu \mathrm{M})$ & - & $+\mathrm{L} 4(10 \mu \mathrm{M})$ \\
\hline PC3 & $<5$ & $53 \pm 7$ & $<5$ & $22 \pm 3$ & $<5$ & $35 \pm 7$ \\
\hline PC3-PTEN & $<5$ & $7 \pm 2$ & $<5$ & $18 \pm 5$ & $<5$ & $42 \pm 4$ \\
\hline DU145 & $<5$ & $10 \pm 2$ & $<5$ & $15 \pm 3$ & $<5$ & $55 \pm 6$ \\
\hline
\end{tabular}

ERK activity in PC3 cells. Similar results were obtained with DU145 and PTEN-PC3 cells (data not shown). To elucidate the role of MAPK in regulating the proliferation, cells were seeded and cultured for $24 \mathrm{~h}$, followed by incubation in the presence or absence of MAPK inhibitors and the cell number, $\left[{ }^{3} \mathrm{H}\right]$ thymidine uptake and the cell cycle at 24,48 , and $72 \mathrm{~h}$ of incubation were analysed. In Fig. $7 \mathrm{C}$ we show the effects of PD98059 and U0126 on $\left[{ }^{3} \mathrm{H}\right]$ thymidine uptake evaluated after $48 \mathrm{~h}$ of culture.

To determine whether proliferative signals can be transmitted through the ERK/MAPK pathway, proliferation was quantitatively evaluated in the presence of PD98059 as percentage of the control. In Table 5 we show the additive (A) and synergistic (S) antiprolifera- tive effects of PI-3K and EGFR dual blockade in the eight $\mathrm{PCa}$ cell lines tested. Apoptosis was also measured, and data are shown in Table 6 .

Taken together, the data illustrated in this section indicate that although signalling through the ERK/ MAPK pathway is not obligatory for cell survival, cytoprotective signals can be transmitted through this pathway in response to Erb-B1 activation and that MAPK effectively influences cell proliferation.

\section{Discussion and conclusion}

In this study we have identified the PI3K pathway as an essential mediator of cell survival and the MAPK pathway as an essential mediator of constitutive and
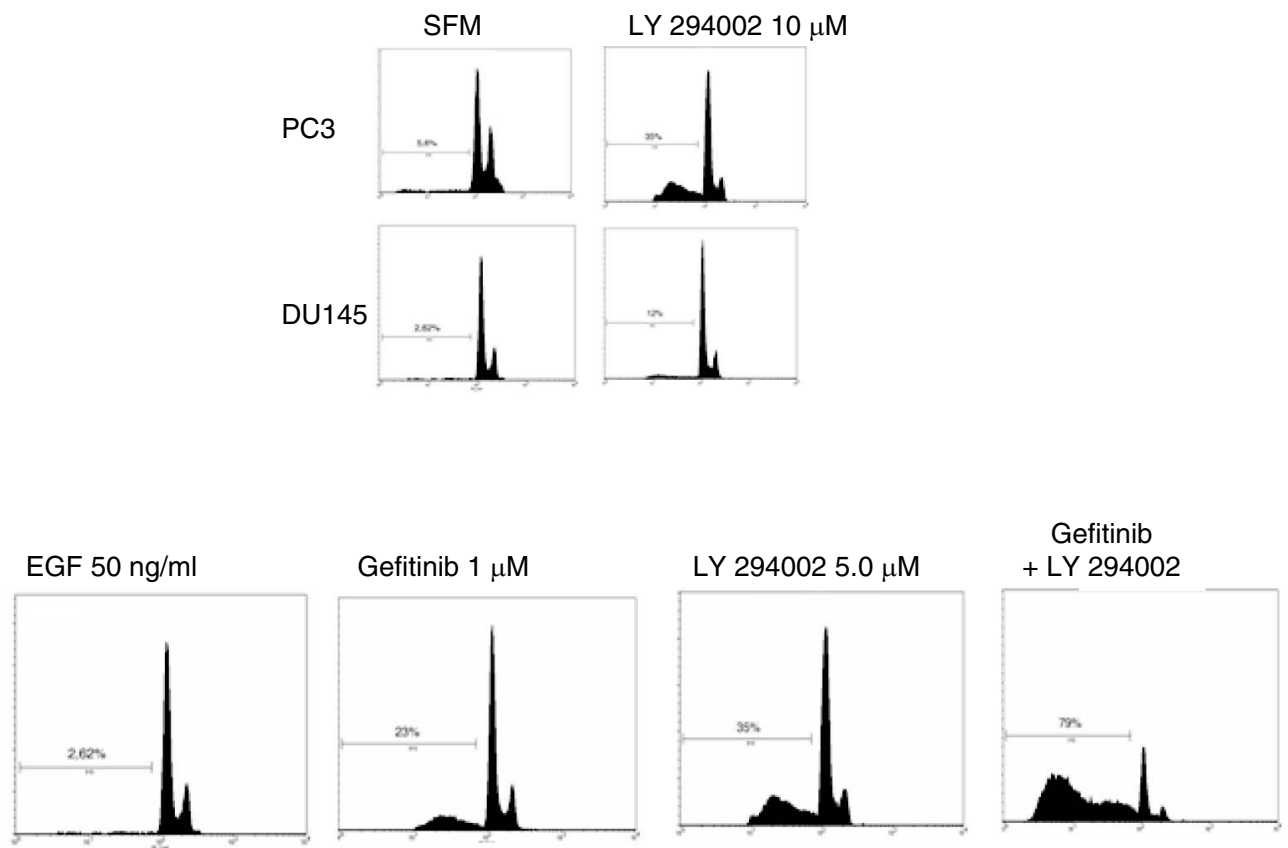

Figure 6 Comparison between PC3 and DU145 cells of LY294002-induced apoptosis under basal conditions. Combined effects of $5 \mu \mathrm{M}$ LY294002 and $1 \mu \mathrm{M}$ gefitinib in PC3 cells are also shown (bottom panels). Cells $\left(1 \times 10^{6}\right)$ were harvested after $48 \mathrm{~h}$ of treatment with $10 \mu \mathrm{M}$ LY294002 and analysed for apoptosis by FACS as described in Materials and methods section. SFM, serum-free medium. 
Table 3 Effects of gefitinib and LY294002 (L4) alone or in combination on apoptosis of PC3, PTEN-PC3 and DU145 cells. Similar differences were observed for other PTEN-negative or -positive cell lines. Apoptotic cells were detected by a quantifiable peak in sub-G1 phase corresponding to the red fluorescence emitted by a sub-diploid nuclei of cells, and the result were expressed as the cell death percentage present in the sample.

\begin{tabular}{lcccc}
\hline & \multicolumn{4}{c}{ EGF (50 ng/ml) } \\
\cline { 2 - 5 } Cell line & Baseline & $\begin{array}{c}\text { Gefitinib } \\
(\mathbf{1} \mu \mathrm{M})\end{array}$ & $\begin{array}{c}\text { LY } \\
\mathbf{1 0} \boldsymbol{\mu M}\end{array}$ & $\begin{array}{c}\text { Gefitinib } \\
+ \text { LY294002 }\end{array}$ \\
\hline PC3 & $<5$ & $23 \pm 4$ & $35 \pm 7$ & $79 \pm 10$ \\
PC3-PTEN & $<5$ & $32 \pm 2$ & $10 \pm 4$ & $75 \pm 7$ \\
DU145 & $<5$ & $40 \pm 6$ & $15 \pm 3$ & $70 \pm 13$ \\
\hline
\end{tabular}

growth factor-activated cell proliferation in PCa cells in vitro. Indeed, attenuation of signalling through PI3K inhibitors triggered a rapid and extensive apoptotic response whereas the inhibition of the MAPK pathway determined primarily a significant reduction of cell proliferation.

PI3K and its downstream effectors can be activated constitutively (PTEN-negative cells) or ligandactivated (PTEN-positve cells) for multiple receptor tyrosine kinases, including receptors for several polypeptide growth factors. MAPK and its downstream effectors can be activated by growth factors including the members of EGFR family through the Ras/Raf/ MAPK pathway (Barnes et al. 2003) and enhanced MAPK activity induces survival in malignant $\mathrm{PCa}$ cells (Zelivienski et al. 2003, Uzgare \& Isaacs 2004). Importantly, however, analysis of PI3K and Akt kinase activities (after LY294002 and EGF treatment) indicated that survival signals stimulated by Erb-B1 ligands are also likely to be transmitted through a PI3K-independent pathway. This was demonstrated by experiments in which the protective effect of Erb-B1 activation by ligand was abolished when LY294002 and PD98059 were used in combination (Knowlden et al. 2003, She et al. 2003, Jelovac et al. 2005). This finding indicates that Erb-B1-activated survival signals can also be transmitted through the ERK/MAPK pathway, despite the fact that the MEK inhibitor, when used alone, did not induce apoptosis.

In parallel to the current results, several recent reports suggest that constitutively active MAPK and Akt may contribute to resistance to EGFR inhibitors. Investigating a panel of tumour cell lines, Janmaat et al. (2003) found that EGFR inhibitors induced growth inhibition in A431 cells but not in a series of lung cancer cell lines. Further, persistent activity of either MAPK or PI3K/Akt pathways was observed in resistant lung cancer lines. Using MDA-468 breast cancer cells, Ciardiello et al. (2000) and She et al. (2003) showed that resistance to gefitinib was associated with loss of PTEN and consequent overactivation of Akt with uncoupling of the Akt pathway from EGFR. Reconstitution of PTEN in these cells re-established EGFR-driven Akt signalling and thereby restored gefitinib sensitivity. These results suggest that MAPK and/or Akt signalling pathways may play a central role in the development of resistance to EGFR inhibitors. To study the effects of gefitinib in $\mathrm{PCa}$ cell lines, we analysed the signalling-pathway molecules p42/44 MAPK and Akt, which are activated by Erb-B receptors and play an important role in receptor-mediated proliferation and apoptosis, as

Table 4 Additive (A) and synergistic (S) pro-apoptotic effects of PI3K and EGFR dual blockade. Apoptotic cells were detected by a quantifiable peak in sub-G1 phase corresponding to the red fluorescence emitted by a sub-diploid nuclei of cells, and the result were expressed as the cell death percentage present in the sample.

\begin{tabular}{lcccc}
\hline Cell line & LY294002 $(\mathbf{1 0} \boldsymbol{\mu M})^{\star}$ & Gefitinib $\mathbf{( 0 . 1} \boldsymbol{\mu M}) \dagger$ & LY294002+Gefitinib $\ddagger$ & Effect \\
\hline PC3 & $25.4 \pm 5.0$ & $7.5 \pm 2.1$ & $55.0 \pm 10.5$ & $\mathrm{~S}$ \\
PC3-PTEN & $4.0 \pm 1.5$ & $16.0 \pm 4.5$ & $19.0 \pm 6.0$ & $\mathrm{~A}$ \\
ALVA31 & $25.0 \pm 4.5$ & $5.0 \pm 3.0$ & $50.5 \pm 12.5$ & $\mathrm{~S}$ \\
TSU-Pr1 & $28.4 \pm 3.5$ & $4.5 \pm 2.7$ & $27.5 \pm 3.7$ & $\mathrm{~S}$ \\
DU145 & $7.0 \pm 1.4$ & $24.7 \pm 5.5$ & $30.3 \pm 4.5$ & $\mathrm{~A}$ \\
ND1 & $5.4 \pm 1.2$ & $25.3 \pm 3.7$ & $45.3 \pm 7.5$ & $\mathrm{~A}$ \\
CWR22R-2152 & $10.3 \pm 3.5$ & $21.4 \pm 3.7$ & $65.7 \pm 13.5$ & $\mathrm{~A}$ \\
LnCaP & $15.4 \pm 5.2$ & $20.5 \pm 3.5$ & $\mathrm{~S}$ \\
\hline
\end{tabular}

*Mean of LY29402-induced cell apoptosis was $23.5 \pm 5.6$ (mean \pm sD) for PTEN-null cells and $6.7 \pm 2.7$ for PTEN positive cells $(P<0.005)$.

† Mean of gefitinib-induced cell apoptosis was $9.4 \pm 3.8$ for PTEN-null cells and $21.8 \pm 2.1$ for PTEN-positive cells $(P<0.05)$.

$\ddagger$ Mean of combination-treatment-induced cell apoptosis was $60.0 \pm 2.2$ for PTEN-null cells and $30.5 \pm 5.5$ for PTEN-positive cells $(P<0.005)$.

Apoptosis was measured as percentage of apoptotic cells. 
A

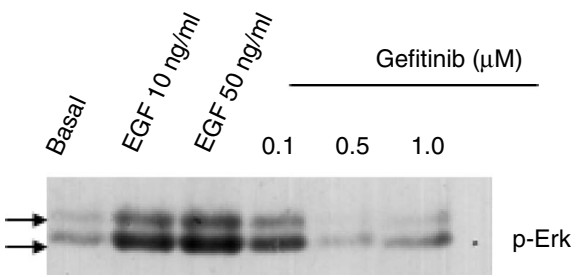

B
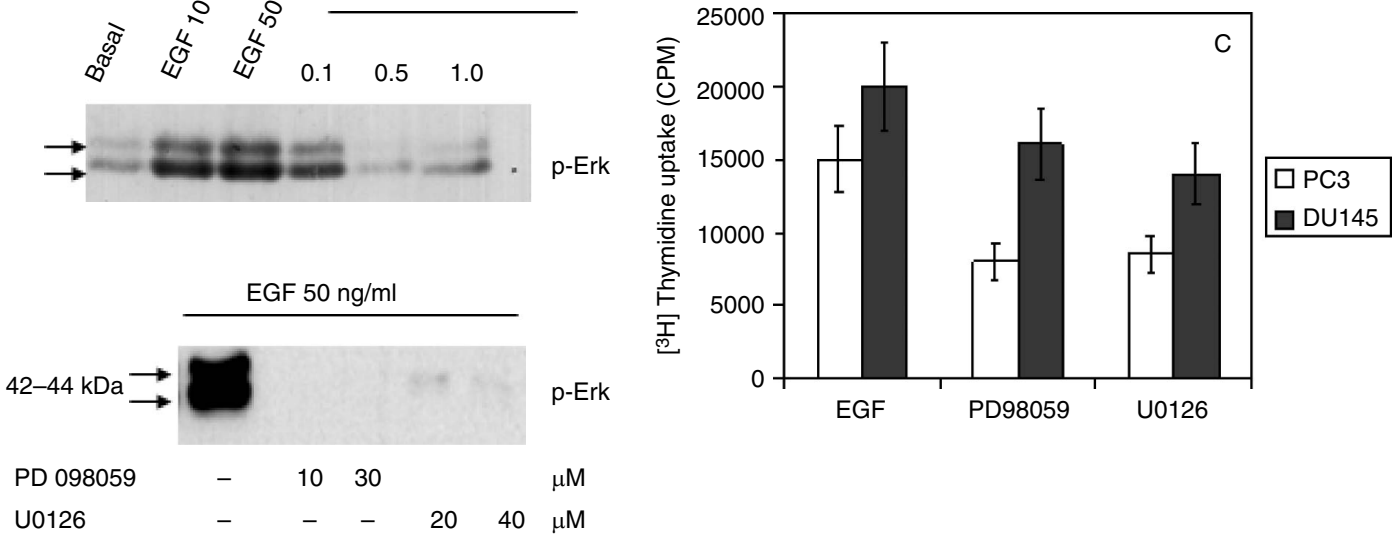

Figure 7 ERK activation in PC3 cells (A, B) by EGF (10-50 ng/ml) added for $30 \mathrm{~min}$ to cells in the absence of serum. Gefitinib $(0.1-1.0 \mu \mathrm{M})$, added $15 \mathrm{~min}$ before EGF $(50 \mathrm{ng} / \mathrm{ml})$, inhibited EGF-induced ERK activation totally, as did two MAPK inhibitors (B), PD98059 and U0126. PC3 and DU145 cells were inhibited by optimal doses of MAPK inhibitors. Cells $\left(5 \times 10^{4}\right)$ were plated in a $50 \mathrm{~mm}$ petri dishes, left to adhere overnight and treated with $50 \mathrm{ng} / \mathrm{ml}$ EGF and different MAPK inhibitors were added $15 \mathrm{~min}$ before EGF treatment. Cells were analysed after 4 days of culture and treated with $\left[{ }^{3} \mathrm{H}\right]$ thymidine, as described in the Materials and methods section, $16 \mathrm{~h}$ before measuring the incorporated radiation. The data are expressed as means \pm S.D. The results are representative of at least three independent experiments.

already described. EGF induced phosphorylation of Akt only in PTEN-positive cells and this phosphorylation was completely prevented in the presence of gefitinib, whereas p42/44 MAPK was phosphorylated both in PTEN-negative and -positive cells after EGF treatment. This inhibition of downstream signalling occurred at the same gefitinib concentration that inhibited EGF-induced phosphorylation of EGFR. In addition we compared the effects of gefitinib with PTEN expression and constitutive and activated Akt and ERK activities. We indicated that PTEN is positively related to gefitinib activity and its loss determines a reduced effectiveness of the drug. The basal activity of Akt as well as of ERK are negative mediators of gefitinib effectiveness. High levels of Akt through a downregulation or loss of PTEN cause a reduced sensitivity of cells to gefitinib treatment. Thus combined treatments with pharmacological inhibitors of PI3K are highly synergistic in these cells. PTENpositive cells, which possess very low levels of Akt, are

Table 5 Additive (A) and synergistic (S) antiproliferative effects of MAPK and EGFR dual blockade. Antiproliferative effects were measured as \% of inhibition vs control.

\begin{tabular}{|c|c|c|c|c|}
\hline Cell line & PD98059 $(30 \mu \mathrm{M})^{\star}$ & Gefitinib $(0.1 \mu \mathrm{M}) \dagger$ & PD $+($ Gefitinib $) \ddagger$ & Effect \\
\hline PC3 & $3.0 \pm 0.5$ & $3.5 \pm 2.1$ & $7.6 \pm 1.3$ & $A$ \\
\hline PC3-PTEN & $3.0 \pm 0.7$ & $30.0 \pm 4.5$ & $23.0 \pm 0.5$ & A \\
\hline ALVA31 & $15.0 \pm 0.3$ & $10.0 \pm 2.5$ & $45.5 \pm 0.7$ & $S$ \\
\hline TSU-Pr1 & $15.6 \pm 3.2$ & $10.5 \pm 3.5$ & $45.9 \pm 1.7$ & $S$ \\
\hline DU145 & $17.6 \pm 2.7$ & $34.7 \pm 4.1$ & $65.6 \pm 7.7$ & $S$ \\
\hline ND1 & $20.1 \pm 2.5$ & $35.3 \pm 2.7$ & $68.2 \pm 6.5$ & $S$ \\
\hline CWR22R-2152 & $5.3 \pm 0.5$ & $27.4 \pm 3.7$ & $30.0 \pm 3.1$ & $A$ \\
\hline LnCaP & $5.4 \pm 0.7$ & $32.5 \pm 2.5$ & $25.5 \pm 7.9$ & $A$ \\
\hline
\end{tabular}

*Mean of PD98059-induced cell-growth inhibition (\% vs control) was $9.8 \% \pm 3.2 \%$ (mean \pm SD) for PTEN-null cells and $11.5 \% \pm 4.3 \%$ for PTEN-positive cells $(P=0.756)$. This parameter was significantly co-related to $p$-Erk basal activity shown in Table 1 with $r=0.708$ and $P=0.049$.

$\dagger$ †ean of gefitinib-induced cell-growth inhibition (\% vs control) was $14.1 \% \pm 3.8 \%$ for PTEN-null cells and $31.8 \% \pm 1.9 \%$ for PTENpositive cells $(P<0.05)$.

$\ddagger$ Mean of combination-treatment-induced cell-growth inhibition ( $\%$ vs control) was $31.1 \% \pm 9.2 \%$ for PTEN-null cells and $46.7 \% \pm 11.8 \%$ for PTEN-positive cells $(P=0.337)$. 
Table 6 Additive $(\mathrm{A})$, synergistic $(\mathrm{S})$ or null $(\mathrm{N})$ pro-apoptotic effects of MAPK and EGFR dual blockade. Apoptotic cells were detected by a quantifiable peak in sub-G1 phase corresponding to the red fluorescence emitted by a sub-diploid nuclei of cells, and the result were expressed as the cell death percentage present in the sample.

\begin{tabular}{|c|c|c|c|c|}
\hline Cell line & PD98059 $(30 \mu \mathrm{M})^{\star}$ & Gefitinib $(0.1 \mu \mathrm{M}) \dagger$ & PD + Gefitinib $\ddagger$ & Effect \\
\hline PC3 & 0.8 & $7.5 \pm 2.1$ & $10.0 \pm 10.5$ & $\mathrm{~N}$ \\
\hline PC3-PTEN & 0.8 & $16.0 \pm 4.5$ & $19.0 \pm 6.0$ & $\mathrm{~N}$ \\
\hline ALVA31 & 0.8 & $10.0 \pm 3.0$ & $10.5 \pm 2.5$ & $\mathrm{~N}$ \\
\hline TSU-Pr1 & $10.4 \pm 3.5$ & $10.3 \pm 2.7$ & $48.9 \pm 13.5$ & $S$ \\
\hline DU145 & $11.0 \pm 1.4$ & $24.7 \pm 5.5$ & $47.5 \pm 3.7$ & $S$ \\
\hline ND1 & $111.4 \pm 1.2$ & $25.3 \pm 3.7$ & $30.3 \pm 3.6$ & $A$ \\
\hline CWR22R-2152 & $8.3 \pm 3.5$ & $21.4 \pm 3.7$ & $27.3 \pm 4.7$ & $A$ \\
\hline LnCaP & 5.5 & $27.5 \pm 3.5$ & $30.7 \pm 5.5$ & $A$ \\
\hline
\end{tabular}

*Mean of PD98059-induced cell apoptosis was $4.4 \pm 2.3$ (mean \pm sD) for PTEN-null cells and $7.9 \pm 2.5$ for PTEN-positive cells $(P=0.342)$. This parameter was not related with $\mathrm{p}$-Erk basal activity shown in Table 1 with $r=0.354$ and $P=0.390$.

† Mean of gefitinib-induced cell apoptosis was $9.4 \pm 3.8$ for PTEN-null cells and $21.8 \pm 2.1$ for PTEN-positive cells $(P<0.05)$. $\ddagger$ Mean of combination-treatment-induced cell apoptosis was $25.0 \pm 9.3$ for PTEN-null cells and $31.0 \pm 6.0$ for PTEN-positive cells $(P=0.607)$.

Apoptosis was measured as percentage of apoptotic cells.

stimulated in this way by EGFR triggering. In fact, EGF induces Akt activation, which is reduced by gefitinib treatment. In these cells the combination with PI3K inhibitors determines only very weak additive effects. Similarly, high basal levels of ERK activity cause a reduced sensitivity of cells to gefitinib treatment. In this case, the combined treatments with pharmacological inhibitors of MAPK are highly synergistic in cells possessing elevated p-ERK levels (TSU-Pr1, DU145 and ND1 cells) independently to PTEN status. As previously described, gefitinib effectiveness was independent of EGFR levels whereas an increased expression of Her2 was a negative parameter for predicting gefitinib effectiveness. This is in agreement with our observation in primary cultures of PCa treated with an anti-androgen receptor such as Casodex, in which increased expression of Her2 with decreased expression of PTEN inhibit the effects of gefitinib (C Festuccia, P Muzi, D Millimaggi, L Biordi, G L Gravina, S Speca, A Angelucci, V Dolo, C Vicentini, M Bologna, unpublished work) or with the observations in vivo in CWR22 relapsed xenografts after long-term treatment with gefitinib in which the drug resistance seems to be associated with Her2 increment.

Taken together, our results indicate that gefitinib treatment could be used as a monotherapy only in PCa cells that express PTEN protein and possess low basal p-ERK levels. Nevertheless, it is also possible that these selected cell populations can present de novo resistance to gefitinib after prolonged treatment with the drug, through an increased activity of ERK due to the increment of other growth factor receptors GFR including insulin-like growth factor I receptor
(IGF-IR; Yamakoa et al. 2002, Jones et al. 2004, Camirand et al. 2005) or the Trk family, as some unpublished data of ours indicate. Therefore, gefitinib could be conveniently used in combination treatment schedules with (1) PI3K/Akt pathway inhibitors (for example with the pharmacologically active PI3K inhibitor, perifosine (Van Ummersen et al. 2004, Vink et al. 2005) or with mammalian target of rapamycin (mTOR) inhibitors (for reviews see Goudar et al. 2005, Vignot et al. 2005), (2) Ras/Raf/MAPK-pathway inhibitors or (3) IGF-IR inhibitors, which can be useful to slow down the onset of drug-resistant cells and possibly to control the progression and the proliferation in advanced PCas.

\section{Acknowledgements}

Gefitinib is a trademark of the AstraZeneca group of companies. The authors declare that there is no conflict of interest that would prejudice the impartiality of this scientific work.

\section{References}

Abate-Shen C, Banach-Petrosky WA, Sun X, Economides KD, Desai N, Gregg JP, Borowsky AD, Cardiff RD \& Shen MM 2003 Nkx3.1; Pten mutant mice develop invasive prostate adenocarcinoma and lymph node metastases. Cancer Research 63 3886-3890.

Arteaga CL \& Johnson DH 2001 Tyrosine kinase inhibitorsZD1839 (Iressa). Current Opinion in Oncology 13 491-498.

Asakuma J, Sumitomo M, Asano T, Asano T \& Hayakawa M 2004 Modulation of tumor growth and tumor induced angiogenesis after epidermal growth factor receptor 
inhibition by ZD1839 in renal cell carcinoma. Journal of Urology 171 897-902.

Barton J, Blackledge G \& Wakeling A 2001 Growth factors and their receptors: new targets for prostate cancer therapy. Urology 58 (Suppl 2A) 114-122.

Barnes CJ, Bagheri-Yarmand R, Mandal M, Yang Z, Clayman GL, Hong WK \& Kumar R 2003 Suppression of epidermal growth factor receptor, mitogen-activated protein kinase, and Pak1 pathways and invasiveness of human cutaneous squamous cancer cells by the tyrosine kinase inhibitor ZD1839 (Iressa). Molecular Cancer Therapy 2 345-351.

Baselga J 2001 Clinical trials of Herceptin (trastuzumab). European Journal of Cancer 37 18-23.

Brader S \& Eccles SA 2004 Phosphoinositide 3-kinase signalling pathways in tumor progression, invasion and angiogenesis. Tumori 90 2-8.

Camirand A, Zakikhani M, Young F \& Pollak M 2005 Inhibition of insulin-like growth factor-1 receptor signaling enhances growth-inhibitory and proapoptotic effects of gefitinib (Iressa) in human breast cancer cells. Breast Cancer Research 7 570-579.

Ciardiello F, Caputo R, Bianco R, Damiano V, Pomatico G, De Placido S, Bianco AR \& Tortora G 2000 Antitumor effect and potentiation of cytotoxic drugs activity in human cancer cells by ZD-1839 (Iressa), an epidermal growth factor receptor-selective tyrosine kinase inhibitor. Clinical Cancer Research 6 2053-2063.

Cohen EEW, Rosen F, Dekker A, Bajda C, Stenson K, Shulman KL, Lamont E, Kozloff M \& Vokes EE 2002 Phase II study of ZD1839 (Iressa) in recurrent or metastatic squamous cell carcinoma of the head and neck (SCCHN). Proceedings of the American Society for Clinical Oncology 21 225a (A899).

Connolly JM \& Rose DP 1991 Autocrine regulation of DU145 human prostate cancer cell growth by epidermal growth factor-related polypeptides. Prostate 19 173-180.

Culig Z, Hobisch A, Cronauer MV, Radmayr C, Hittmair A, Zhang J, Thurnher M, Bartsch G \& Klocker H 1996 Regulation of prostatic growth and function by peptide growth factors. Prostate 28 392-405.

Di Loreto G, Tortora G, D'Armiento FP, De Rosa G, Staibano S, Autorino R, D'Armiento M, De Laurentiis M, De Placido S, Catalano G et al. 2002 Expression of epidermal growth factor receptor correlates with disease relapse and progression to androgen-independence in human prostate cancer. Clinical Cancer Research $\mathbf{8}$ 3438-3444.

Djakiew D 2000 Dysregulated expression of growth factors and their receptors in the development of prostate cancer. Prostate 42 150-160.

Dreher T, Zentgraf H, Abel U, Kappeler A, Michel MS, Bleyl U \& Grobholz R 2004 Reduction of PTEN and p27kipl expression correlates with tumor grade in prostate cancer. Analysis in radical prostatectomy specimens and needle biopsies. Virchows Archiv 444 509-517.
El Sheikh SS, Domin J, Abel P, Stamp G \& Lalani el-N 2004 Phosphorylation of both EGFR and ErbB2 is a reliable predictor of prostate cancer cell proliferation in response to EGF. Neoplasia 6 846-853.

Festuccia C, Gravina GL, Angelucci A, Millimaggi D, Muzi P, Vicentini C \& Bologna M 2005 Additive antitumor effects of the epidermal growth factor receptor tyrosine kinase inhibitor, gefitinib (Iressa), and the nonsteroidal antiandrogen, bicalutamide (Casodex), in prostate cancer cells in vitro. International Journal of Cancer 115 630-640.

Fukuoka M, Yano S, Giaccone G, Tamura T, Nakagawa K, Douillard J-Y, Nishiwaki JF, Vansteenkiste S, Kudo S, Averbuch S et al. 2002 Final results from a phase II trial of ZD1839 ('Iressa') for patients with advanced non-small-cell lung cancer (IDEAL 1). Proceedings of the American Society for Clinical Oncology 21 298a (A1188).

Geller JA, Galkin AV, Mullen L, Tindell CA, Fox WD, Scher HI \& Agus DB 2002 Effects of the epidermal growth factor receptor tyrosine kinase inhibitor (EGFR-TKI) ZD1839 ('Iressa') on androgen-dependent and androgen-independent human prostate tumour xenografts: growth inhibition and characteristics of resistant tumours. American Association for Cancer Research International Conference Abstract 4971.

Gioeli D, Mandell JW, Petroni GR, Frierson Jr HF \& Weber MJ 1999 Activation of mitogen-activated protein kinase associated with prostate cancer progression. Cancer Research 59 279-284.

Goss GD, Stewart DJ, Hirte H, Miller W, Major P, Batist G, Mathews S, Douglas L, Lorimer I \& Seymour L 2002 Initial results of part 2 of a phase I/II pharmacokinetic, pharmacodynamic and biological activity study of ZD1839 ('Iressa'): National Cancer Institute of Canada - Clinical trials group IND.122. Proceedings of the American Society for Clinical Oncology 2116 (A59).

Goudar RK, Shi Q, Hjelmeland MD, Keir ST, McLendon RE, Wikstrand CJ, Reese ED, Conrad CA, Traxler P, Lane HA et al. 2005 Combination therapy of inhibitors of epidermal growth factor receptor/vascular endothelial growth factor receptor 2 (AEE788) and the mammalian target of rapamycin (RAD001) offers improved glioblastoma tumor growth inhibition. Molecular Cancer Therapy 4 101-112.

Gravina GL, Festuccia C, Angelucci A, Poletti A, Capuano D, Vicentini C, Motta M \& Bologna M 2004 Long-term presence of androgens and anti-androgens modulate EGF-receptor expression and MAP-kinase phosphorylation in androgen receptor-prostate positive cancer cells. International Journal of Oncology 25 97-104.

Herbst RS \& Kies MS 2002 ZD1839 (Iressa ${ }^{\mathrm{TM}}$ ) in non-small cell lung carcinoma. The Oncologist 7 (Suppl 4) 9-15.

Itoh N, Patel U \& Skinner MK 1998 Developmental and hormonal regulation of transforming growth factor-alpha and epidermal growth factor receptor gene expression in isolated prostatic epithelial and stromal cells. Endocrinology 139 1369-1377. 
Izumi T, Yazaki T, Kanoh S, Kondo I \& Koiso K 1987 Establishment of a new prostatic carcinoma cell line (TSU-Pr1). Journal of Urology 137 1304-1306.

Janmaat ML, Kruyt FA, Rodriguez JA \& Giaccone G 2003 Response to epidermal growth factor receptor inhibitors in non-small cell lung cancer cells: limited antiproliferative effects and absence of apoptosis associated with persistent activity of extracellular signal-regulated kinase or Akt kinase pathways. Clinical Cancer Research 9 2316-2326.

Jelovac D, Sabnis G, Long BJ, Macedo L, Goloubeva OG \& Brodie AM 2005 Activation of mitogen-activated protein kinase in xenografts and cells during prolonged treatment with aromatase inhibitor letrozole. Cancer Research $\mathbf{6 5}$ 5380-5389.

Jones HE, Goddard L, Gee JM, Hiscox S, Rubini M, Barrow D, Knowlden JM, Williams S, Wakeling AE \& Nicholson RI 2004 Insulin-like growth factor-I receptor signalling and acquired resistance to gefitinib (ZD1839; Iressa) in human breast and prostate cancer cells. Endocrine-related Cancer 11 793-814.

Kim MJ, Cardiff RD, Desai N, Banach-Petrosky WA, Parsons R, Shen MM \& Abate-Shen C 2002 Cooperativity of $\mathrm{Nkx} 3.1$ and Pten loss of function in a mouse model of prostate carcinogenesis. PNAS 99 2884-2889.

Knowlden JM, Hutcheson IR, Jones HE, Madden T, Gee JM, Harper ME, Barrow D, Wakeling AE \& Nicholson RI 2003 Elevated levels of epidermal growth factor receptor/c-erbB2 heterodimers mediate an autocrine growth regulatory pathway in tamoxifen-resistant MCF-7 cells. Endocrinology 144 1032-1044.

Lorusso PM 2003 Phase I studies of ZD1839 in patients with common solid tumors. Seminars in Oncology 30 21-29.

Loop SM, Rozanski TA \& Ostenson RC 1993 Human primary prostate tumor cell line, ALVA-31: a new model for studying the hormonal regulation of prostate tumor cell growth. Prostate 22 93-108.

Mazzucchelli R, Barbisan F, Tarquini LM, Galosi AB \& Stramazzotti D 2004 Molecular mechanisms in prostate cancer. A review. Analytical \& Quantitative Cytology \& Histology 26 127-133.

Narayan P \& Dahiya R 1992 Establishment and characterization of a human primary prostatic adenocarcinoma cell line (ND-1). Journal of Urology 148 $1600-1604$.

Natale RB 2004 Effects of ZD1839 (Iressa, gefitinib) treatment on symptoms and quality of life in patients with advanced non-small cell lung cancer. Seminars in Oncology 31 23-30.

Ono M, Hirata A, Kometani T, Miyagawa M, Ueda S, Kinoshita H, Fujii T \& Kuwano M 2004 Sensitivity to gefitinib (Iressa, ZD1839) in non-small cell lung cancer cell lines correlates with dependence on the epidermal growth factor (EGF) receptor/extracellular signalregulated kinase $1 / 2$ and $E G F$ receptor/Akt pathway for proliferation. Molecular Cancer Therapy 3 465-472.
Osaki M, Oshimura M \& Ito H 2004 PI3K-Akt pathway: its functions and alterations in human cancer. Apoptosis 9 667-676.

Pfeil K, Eder IE, Putz T, Ramoner R, Culig Z, Ueberall F, Bartsch G \& Klocker H 2004 Long-term androgenablation causes increased resistance to PI3K/Akt pathway inhibition in prostate cancer cells. Prostate 58 259-268.

Ranson M 2002 ZD1839 (Iressa $^{\mathrm{TM}}$ ): for more than just non-small cell lung carcinoma. The Oncologist 7 16-24.

She QB, Solit D, Basso A \& Moasser MM 2003 Resistance to gefitinib in PTEN-null HER-overexpressing tumor cells can be overcome through restoration of PTEN function or pharmacologic modulation of constitutive phosphatidylinositol 3'-kinase/Akt pathway signaling. Clinical Cancer Research 9 4340-4346.

Sirotnak FM, She Y, Lee F, Chen J \& Scher HI 2002 Studies with CWR22 xenografts in nude mice suggest that ZD1839 may have a role in the treatment of both androgen-dependent and androgen-independent human prostate cancer. Clinical Cancer Research $\mathbf{8}$ 3870-3876.

Slamon DJ, Leyland-Jones B, Shak S, Fuchs H, Paton V, Bajamonde A, Fleming T, Eiermann W, Wolter J, Pegram M et al. 2001 Use of chemotherapy plus a monoclonal antibody against HER2 for metastatic breast cancers that over-express HER2. New England Journal of Medicine 344 783-792.

Stahl JM, Sharma A, Cheung M, Zimmerman M, Cheng JQ, Bosenberg MW, Kester M, Sandirasegarane L \& Robertson GP 2004 Deregulated Akt3 activity promotes development of malignant melanoma. Cancer Research 64 7002-7010.

Tepper CG, Boucher DL, Ryan PE, Ma AH, Xia L, Lee LF, Pretlow TG \& Kung HJ 2002 Characterization of a novel androgen receptor mutation in a relapsed CWR22 prostate cancer xenograft and cell line. Cancer Research 62 6606-6614.

Uzgare AR \& Isaacs JT 2004 Enhanced redundancy in Akt and mitogen-activated protein kinase-induced survival of malignant versus normal prostate epithelial cells. Cancer Research 64 6190-6199.

Van Ummersen L, Binger K, Volkman J, Marnocha R, Tutsch K, Kolesar J, Arzoomanian R, Alberti D \& Wilding G 2004 A phase I trial of perifosine (NSC 639966) on a loading dose/maintenance dose schedule in patients with advanced cancer. Clinical Cancer Research $107450-7456$.

Vicentini C, Festuccia C, Gravina GL, Angelucci A, Marronaro A \& Bologna M 2003 Prostate cancer cell proliferation is strongly reduced by the epidermal growth factor receptor tyrosine kinase inhibitor ZD1839 in vitro on human cell lines and primary cultures. Journal of Cancer Research \& Clinical Oncology 129 165-174. 
Vignot S, Faivre S, Aguirre D \& Raymond E 2005 mTORtargeted therapy of cancer with rapamycin derivatives. Annals of Oncology 16 525-537.

Vink SR, Schellens JH, van Blitterswijk WJ \& Verheij M 2005 Tumor and normal tissue pharmacokinetics of perifosine, an oral anti-cancer alkylphospholipid. Investigations into New Drugs 23 279-286.

Wang G, Reed E \& Li QQ 2004 Apoptosis in prostate cancer: progressive and therapeutic implications. International Journal of Molecular Medicine 4 23-34.

Wolf M, Swaisland H \& Averbuch S 2004 Development of the novel biologically targeted anticancer agent gefitinib: determining the optimum dose for clinical efficacy. Clinical Cancer Research 10 4607-4613.

Yamakoa T, Ohmori T, Kadofuku T, Noda M, Tsukiyama F, Koizumi K, Nishio K, Saijo N, Kawaguchi T, Adachi
M \& Kuroki T 2002 Characteristics and resistance mechanism(s) of human non-small-cell lung cancer cell lines with acquired resistance to an epidermal growth factor receptor tyrosine kinase inhibitor. American Association for Cancer Research International Conference Abstract 3886.

Zelivianski S, Spellman M, Kellerman M, Kakitelashvilli V, Zhou XW, Lugo E, Lee MS, Taylor R, Davis TL, Hauke R \& Lin MF 2003 ERK inhibitor PD98059 enhances docetaxel-induced apoptosis of androgen-independent human prostate cancer cells. International Journal of Cancer 107 478-485.

Zhao H, Dupont J, Yakar S, Karas M \& LeRoith D 2004 PTEN inhibits cell proliferation and induces apoptosis by downregulating cell surface IGF-IR expression in prostate cancer cells. Oncogene 23 786-794. 